Proceedings

\title{
Enrichment of Protein and Antioxidants of Cupcake with Moringa (Moringa oleifera) Leaf Powder and Sensorial Acceptability ${ }^{\dagger}$
}

\author{
Alejandra Chinchilla, Susana Rubio-Arraez, Marisa L. Castelló and María Dolores Ortolá* \\ Institute of Food Process Engineering for Development, Universitat Politècnica de València, Camino de Vera \\ s/n, 46022 Valencia, Spain; alechinchita2193@gmail.com (A.C.); suruar@upvnet.upv.es (S.R.-A.); \\ mcasgo@upv.es (M.L.C.) \\ * Correspondence: mdortola@tal.upv.es \\ † Presented at the 2nd International Conference of Ia ValSe-Food Network, Lisbon, Portugal, \\ 21-22 October 2019.
}

Published: 5 August 2020

\begin{abstract}
Moringa oleifera plants have an extensive range of bioactive compounds (carbohydrates, phenolic compounds, lipids and fatty acids, proteins and functional peptides). These molecules may be included in several food matrices, such as bakery products, to improve their nutritional values. For that, the aim of this study was to replace the part of wheat flour with $1 \%, 2.5 \%, 5 \%$ and $10 \%$ of moringa leaf powder in cupcakes, assessing their antioxidant capacity, protein content and sensorial acceptability. The results showed that proteins and antioxidant capacity directly increased with moringa content. However, according to the tasters, these moringa-rich cupcakes were too dark.
\end{abstract}

Keywords: antioxidant capacity; cupcakes; moringa; proteins; sensorial analysis

\section{Introduction}

Moringa is a plant grown in the north of India, Spain, Africa, the Middle East and South America, being Moringa oleifera the most cultivated species. Their leaves contain several nutrients such as vitamins, minerals, amino acids, $\beta$-carotenes, antioxidants, fiber and proteins (19-29\%) with low caloric levels [1-3]. Due to their nutritional components, dried leaves have been used to fortify different food products such as soups, pasta, breads, cakes and cookies [4].

In this regard, the aim of this study was to evaluate the level of wheat flour replacement by dried moringa powder $(0 \%, 1 \%, 2.5 \%, 5 \%$ and $10 \%)$ on the water, protein and antioxidant capacity in cupcakes. Furthermore, a sensorial assessment was carried out to estimate the acceptability of these products.

\section{Materials and Methods}

\subsection{Materials}

Dried moringa leaves, grown in the Valencia region, were ground in a blender (Thermomix, TM31, Vorwerk, Wupertal, Germany) for 3 min at maximum speed (10,000 rpm). Then, the powder was passed through a $0.1 \mathrm{~mm}$ mesh sieve and it was stored at room temperature in a sealed glass jar protected from light. 


\subsection{Preparation of Cupcakes}

Cupcakes were prepared with the following components $(w / w): 25 \%$ of eggs, $25 \%$ of sucrose, $25 \%$ of wheat flour and/or leaf moringa powder, $12 \%$ of sunflower oil, $12 \%$ of milk and $2 \%$ of baking powder. Firstly, eggs were beaten in an electrical blender (Kenwood Ltd, KM240 serie, New Lane, Havant, UK) for ten minutes at maximum rate. After that, sucrose was added, and the mixture was blended for 5 more minutes. Then, milk and oil were incorporated, and the batter was mixed for 2 min at a low rate. Finally, wheat flour/moringa and baking powder were aggregated in the batter, and it was blended for $5 \mathrm{~min}$ at a low rate. The batter was left to stand in a refrigerator for $30 \mathrm{~min}$. Next, muffin paper cups $(60 \times 35 \mathrm{~mm})$ were filled with $65 \mathrm{~g}$ of batter and they were baked at $145{ }^{\circ} \mathrm{C}$ for $23 \mathrm{~min}$ in a semi industrial oven (Rational AGD-86899, Landsberg am Lech, Germany).

Depending on the degree of wheat flour replacement, five formulations were prepared: $\mathrm{M} 0 \%$ (without moringa), M1\%, M2.5\%, M5\% and M10\% when the degree of replacement was $1 \%, 2.5 \%, 5 \%$ and $10 \%$, respectively.

\subsection{Analytical Determinations}

Moisture content was obtained by means of the gravimetric method [5]. Protein content was determined by the Kjeldahl method [6]. An adaptation of the spectrophotometric DPPH method [7,8] was used to analyze the antioxidant capacity. For that, the percentage of free radical DPPH inhibition was registered according to the following equation:

$$
\% D_{\text {reduction }}=100 \cdot\left[\frac{A_{\text {control }}-A_{\text {sample }}}{A_{\text {control }}}\right]
$$

where: $A_{\text {control }}=$ absorbance of initial DPPH (without sample) and $A_{\text {sample }}=$ absorbance after $30 \mathrm{~min}$ of sample addition [9].

\subsection{Sensorial Analysis}

Acceptance of cupcakes formulated with different percentages of moringa powder (M1\%, $\mathrm{M} 2.5 \%$ and M5\%) was analyzed with a panel composed of 30 panellists between 18 and 60 years of age. This test was performed in a sensorial room according to the rule ISO 4121:2003 [10]. On one hand, a hedonic scale was considered to find out the scores that the taster gave to the formulations depending on the attributes analyzed. On the other hand, a just about right (JAR) scale was used in order to know if the intensity of the attribute should be higher or lower.

\section{Results and Discussion}

Percentages of antioxidant capacity, water and proteins of the cupcakes are shown in Table 1. As can be seen in the table, moringa powder contains a high antioxidant capacity, which comes from compounds such as vitamin C, E and $\beta$-carotene. The antioxidant capacity of cupcakes increased linearly with respect to the percentage of moringa used $(\% \mathrm{DPPH}$ inhibition $=7.4568+7.1074 \%$ Moringa, $\mathrm{R}^{2}=0.9301$ ), showing that the antioxidant power of moringa powder persists after baking.

Table 1. Percentages of water, protein and DPPH inhibition in cupcakes (M) depending on the amount of dried leaf moringa powder $(0 \%, 1 \%, 2.5 \%, 5 \%$ and $10 \%)$ and in moringa powder.

\begin{tabular}{cccc}
\hline Product & Antioxidant Capacity (\% Inhibition) & \% Water & \% Protein \\
\hline M0\% & $1.18 \pm 0.06^{\mathrm{a}}$ & $26.5 \pm 0.8^{\mathrm{a}}$ & $5.81 \pm 0.12^{\mathrm{a}}$ \\
M1\% & $11.41 \pm 0.07^{\mathrm{b}}$ & $28.2 \pm 0.4^{\mathrm{ab}}$ & $6.08 \pm 0.02^{\mathrm{b}}$ \\
M2.5\% & $38.81 \pm 0.01^{\mathrm{c}}$ & $26.8 \pm 1.5^{\mathrm{a}}$ & $6.52 \pm 0.09^{\mathrm{c}}$ \\
M5\% & $40.86 \pm 0.01^{\mathrm{d}}$ & $27.8 \pm 1.0^{\mathrm{ab}}$ & $7.18 \pm 0.10^{\mathrm{d}}$ \\
M10\% & $76.5 \pm 0.2^{\mathrm{e}}$ & $29.33 \pm 0.07 \mathrm{~b}$ & $8.07 \pm 0.10^{\mathrm{e}}$ \\
Moringa powder & $80.16 \pm 0.07^{\mathrm{f}}$ & $7.3 \pm 0.3$ & $29.6 \pm 0.3$ \\
\hline
\end{tabular}

Equal letters mean homogeneous groups obtained in the ANOVA analysis. 
The persistence of the antioxidant activity of moringa after baking may be related to the interaction between the components of the cupcake (mainly proteins) and the active compounds (phenols) [11]. As was expected, protein content increased with the increase in moringa percentage in the product following a linear fitting (\% Protein $=5.8946+0.2264 \%$ Moringa, $R^{2}=0.9864$ ) in coherence with the results found by other authors [12]. Bear in mind that in each formulation, for the theoretical protein content of the traditional components [13] and the protein obtained in the moringa powder (Table 1), no loses were found after baking in these conditions.

The relationship between water and protein content may be related to the strong ability of the dried leaf moringa powder to bind to water, due to its high amount of proteins $[14,15]$. The moringa powder protein has several polar aminoacids such as serine, treonine, proline and glutamine [1]. These polar aminoacids interact with water molecules, so cupcakes that contain moringa powder showed a higher water retention ability.

The lower scores obtained in the attributes of flavor, aroma, aspect and color when the percentage of moringa increased were probably due to the lower height reached in these cases and the great intensity of the green color, although the mechanical properties were well assessed without significant differences, irrespective of the level of moringa in the formulation (Figure 1).

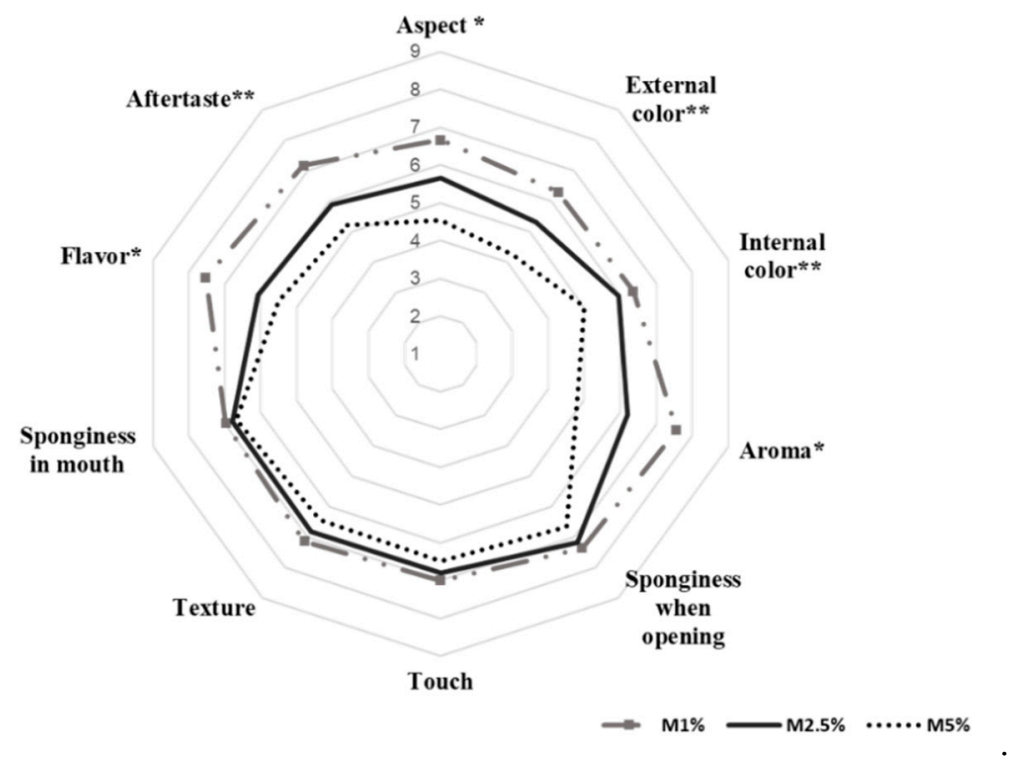

Figure 1. Hedonic scores of cupcakes formulated with moringa. $\left({ }^{*}\right.$ significant level $>95 \%$, significant level > 99\%).

According to the results shown in Figure 2, the greater darkening of cupcakes with the moringa determined the purchase intention. 

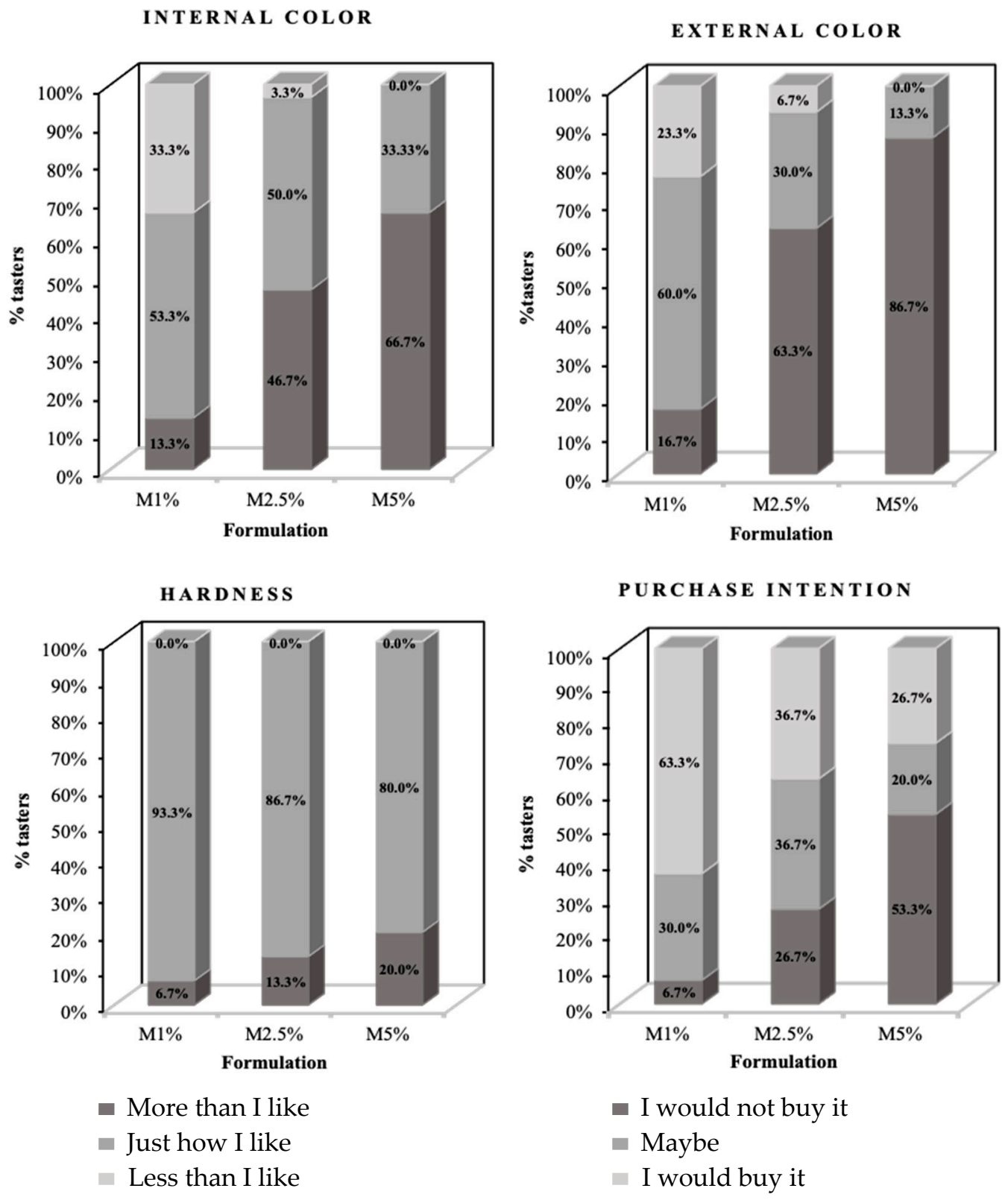

Figure 2. Just about right assessment (JAR) of cupcakes formulated with moringa.

\section{Conclusions}

It is feasible to formulate cupcakes with moringa leaf powder, increasing their antioxidant capacity and protein content. However, more studies should be carried out in order to improve their aspect, flavor and aroma since tasters penalized these attributes as the moringa concentration increased.

Acknowledgments: This work was supported by grant Ia ValSe-Food-CYTED (Ref. 119RT0567) and by the project "New Crops Addressing Climate Change: Moringa and Stevia” (Ref. AGCOOP_A/2018/026 AVFGAGeneralitat Valenciana).

\section{References}

1. Moyo, B.; Masika, P.; Hugo, A.; Muchenje, V. Nutritional characterization of Moringa (Moringa oleifera Lam.) leaves. Afr. J. Biotechnol. 2011, 10, 12925-12933, doi:10.5897/AJB10.1599.

2. Srinivasamurthy, S.; Yadav, U.; Sahay, S.; Singh, A. Development of muffin by incorporation of dried Moringa oleifera (Drumstick) leaf powder with enhanced micronutrient content. Int. J. Food Sci. Nutr. 2017, 2, 173-178. 
3. Abbas, R.K.; Elsharbasy, F.S.; Fadlelmula, A.A. Nutritional Values of Moringa oleifera, Total Protein, Amino Acid, Vitamins, Minerals, Carbohydrates, Total Fat and Crude Fiber, under the Semi-Arid Conditions of Sudan. J. Microb. Biochem. Technol. 2018, 10, 56-58, doi:10.4172/1948-5948.1000396.

4. Oyeyinka, A.; Oyeyinka, S. Moringa oleifera as a food fortificant: Recent trends and prospects. J. Saudi Soc. Agric. Sci. 2018, 17, 127-136, doi:10.1016/j.jssas.2016.02.002.

5. AOAC. Official Methods of Analysis of AOAC International; Determination of moisture content; The Association of Official Analytical Chemists: Gaithersburg, MD, USA, 2000.

6. AOAC. Official Methods of Analysis of AOAC International. Method 928.08; The Association of Official Analytical Chemists: Gaithersburg, MD, USA, 1974.

7. Brand-Williams, W.; Cuvelier, M.; Berset, C. Use of a free radical method to evaluate antioxidant activity. LWT Food Sci. Technol. 1995, 28, 25-30, doi:10.1016/S0023-6438(95)80008-5.

8. Turkemen, N.; Sari, F.; Veliouglu, Y.S. The effect of cooking methods on total phenolics and antioxidant activity of selected green vegetables. Food Chem. 2004, 93, 713-718, doi:10.1016/j.foodchem.2004.12.038.

9. Turkemen, N.; Sari, F.; Veliouglu, Y.S. The effect of cooking methods on total phenolics and antioxidant activity of selected green vegetables. Food Chem. 2004, 93, 713-718, doi:10.1016/j.foodchem.2004.12.038

10. ISO 4121 SA. Guidelines for the Use of Quantitative Responses Scales; International Organization for Standardization: Geneva, Switzerland, 2003.

11. Bourekoua, H.; Rózyło, R.; Gawlik-Dziki, U.; Benatallah, L.; Nasreddine Zidoune, M.; Dziki, D. Evaluation of physical, sensorial, and antioxidant properties of gluten-free bread enriched with Moringa Oleifera leaf powder. Eur. Food Res. Technol. 2017, 244, 189-195, doi:10.100700217-017-2942-y.

12. Abdull, R.; Ahmad, F.; Ibrahim, M.D.; Kntayya, S.B. Health benefits of Moringa oleifera. Asian Pac. J. Cancer Prev. 2014, 15, 8571-8576, doi:10.7314/apjcp.2014.15.20.8571.

13. Bedca. 2019. Spanish Food Composition Database. Available online: http://www.bedca.net/bdpub/index.php (accessed on 1 June 2019).

14. Sun-Young, K.; Chang-Ho, C. Quality Characteristics of Noodles added with Moringa oleifera Leaf Powder. J. East Asian Soc. Diet. Life 2017, 27, 321-331, doi:10.17495/easdl.2017.6.27.3.321.

15. Aryee, A.; Boye, J. Comparative study of the effects of processing on the nutritional, physicochemical and functional properties of lentil. J. Food Process. Pres. 2017, 41, 12824, doi:10.1111/jfpp.12824. 